\title{
Effect of Heat Treatment on Some Mechanical Properties of Laminated Window Profiles Manufactured Using Two Types of Adhesives
}

\section{Derya Sevim Korkut ${ }^{1}$, Suleyman Korkut ${ }^{1, *}$ and Tuncer Dilik ${ }^{2}$}

1 Duzce University, Faculty of Forestry, Dept. of Forest Products Engineering, 81620 Duzce, Turkey; Tel. +90 380 5421137; Fax: +90 380 5421136; E-Mail: deryasevimkorkut@duzce.edu.tr; suleymankorkut@duzce.edu.tr

2 Istanbul University, Faculty of Forestry, Dept. of Forest Products Engineering 34473 BahcekoySariyer, Turkey; Tel. +90 212 2261103; Fax: +90 212 2261113; E-mail: tuncerd@istanbul.edu.tr

* Author to whom correspondence should be addressed; E-Mail: suleymankorkut@duzce.edu.tr

Received: 4 February 2008; in revised form: 25 February 2008 / Accepted: 12 March 2008 /

Published: 2 April 2008

\begin{abstract}
The mechanical properties of laminated window profiles manufactured using two types of adhesives were determined. The objective of this study is to evaluate the effects of heat treatment on some mechanical properties of laminated window profiles that manufactured from Kosipo (Entandrophragma candollei Harms.) using differenet type adhesives. Commercially produced polyurethane based Macroplast UR 7221 and polyvinyl acetate (PVAc) adhesive were used for experiments. The overall test results were found to be comparable to those obtained in the previous studies. Both types of adhesives resulted in significant differences in their strength characteristics at $95 \%$ confidence level. Adhesive UR 7221 improved the overall properties of the samples in contrast to PVAc.
\end{abstract}

Keywords: laminated window profiles, strength properties, macroplast UR 7221, PVAc, Kosipo.

\section{Introduction}

Laminated wood products are becoming popular in various applications such as construction, furniture units, and indoor decorations due to utilization of raw materials with alternative approach. 
Compared with sawn lumber, laminated lumber can be used for creating wood products that are free from defects and are much larger in size than pieces of wood which were sawn. There are also advantageous in that they are dimensionally more stable, have a variable cross-section, and are more attractive than wood products manufactured from solid wood [1-3].

In recent years, development in lamination technology has played an important role in the expansion of the use of laminated lumber. Laminated window profiles are one of the applications of this newly developed products. It has been extensively utilized in the manufacture of window profiles in many European countries because of its efficiency and positive influence on the environment.

Characteristics of adhesive, properties of raw materials such as grain orientation and density, and their manufacturing methods for lamination processes play an important role in determining its final quality. Therefore, it is important to select the right type of adhesive and to control the overall process to obtain laminated products with acceptable strength properties [4,5].

The quality of window profiles manufactured from laminated material is comparable to those made from solid wood. However, extra attention should be paid to laminating variables such as difference in moisture content between layers, which should not exceed $2 \%$ to comply with standards set by German Window Technical Institute (PrEN 386, 1991). However, water-resistant resin should be used where laminated wood is exposed to high relative humidity.

A number of studies was carried out to evaluate lamination techniques and their application as function of species, adhesive type, and layer thickness [1,2,4]. Laufenberg (1982) determined the influence of outdoor conditions on the performance of veneer and solid-wood laminated materials using phenol resorcinol adhesive [6]. Schimid (1984) proposed that layer thickness should be less than $15 \mathrm{~mm}$ to achieve ideal strength properties for the laminated window profiles [7]. Lejeune and Leclercq (1990) utilized various tropical wood species such as merbau and meranti to manufacture laminated window profiles [8]. Turkulin (1992 and 1993) reported strength properties of laminated window profiles made from softwood species using polyvinyl acetate (PVAc) [9-10] .

Many studies have been performed in order to improve the wood properties, and these studies have been commonly named "Wood Modification Methods." However, heat treatment is one of the processes used to modify the properties of wood [11]. The heat treatments are usually performed to improve swelling-shrinkage properties of woods and therefore to increase its dimensional stability and biological resistance against fungus [12].

Industrial-scale heat treatment process for woods was developed at the Technical Research Center of Finland in the early 1990s. The total production capacity of the heat-treated wood in 2002 was approximately estimated to be $265.000 \mathrm{~m}^{3}[13,14]$. Recent efforts with regards to the thermal treatment of wood have led to the development of several treatment processes, and materials produced through thermal treatments have been introduced to the European market. Some of the products developed using thermal treatment include Thermowood (Stellac) in Finland [15], Torrefaction (Perdure) in France, and PLATO-Wood in the Netherlands [16].

The extent of the improvement in wood properties after the heat treatment depends on many factors such as thermal modification approaches, wood species, treatment time, and temperature.

Heat treatment of woods over $150{ }^{\circ} \mathrm{C}$ alters the physical and chemical properties significantly $[13,17]$. It was speculated that the higher the treatment temperature, the better the wood's biological durability. However, the strength properties begin to deteriorate at temperatures over $150{ }^{\circ} \mathrm{C}$. 
The wood becomes more brittle, and bending and tension strength decrease by $10-30 \%$. Therefore, the use of heat-treated wood in load-bearing constructions is restricted [15].

Although heat treatments can be reduced, effects on certain mechanical properties of woods, the dimensional stability, and the biological durability of woods can be increased [12]. However, heattreated wood is an ecofriendly alternative to impregnated wood materials and can be used for aesthetic places such as garden, kitchen, and sauna furniture, cladding on wooden buildings, bathroom cabinets, floor material, musical instruments, ceilings, inner and outer bricks, doors and window joinery, and a variety of other outdoor and indoor wood applications [13].

Currently, there is no information about the effects of heat treatment on the strength properties of laminated window profiles manufactured from Kosipo wood. Therefore, the objective of this study is to evaluate the effects of heat treatment on some mechanical properties of laminated window profiles manufactured from Kosipo (Entandrophragma candollei Harms.) using differenet types of adhesives.

Improving the characteristics of laminated window profiles produced from Kosipo through heat treatment may provide an initial data to the manufacturers and offer interesting opportunities in future.

\section{Experimental Section}

Kosipo wood, a tropical species and usually used as a substitute to mahogany in furniture and sawmilling industry, was utilized for producing laminated window products. Thirty samples with 76 $\mathrm{mm} \times 86 \mathrm{~mm} \times 1000 \mathrm{~mm}$ for each species were manufactured in L shape as illustrated in Figure 1 . Two types of commercial adhesives, namely, Macroplast UR 7221, which is polyurethane-based adhesive, and water-resistant PVAc-type Dorus MD 072 were used for the experiments. Samples were manufactured in the laboratory of Akcam Joinery Inc.Istanbul-Turkey based on GermanWindows Technical Institute standards using a cold press at a pressure of $600 \mathrm{KPa}$ for $20 \mathrm{~min}$ for PVAc and UR 7221 adhesives, respectively [18].

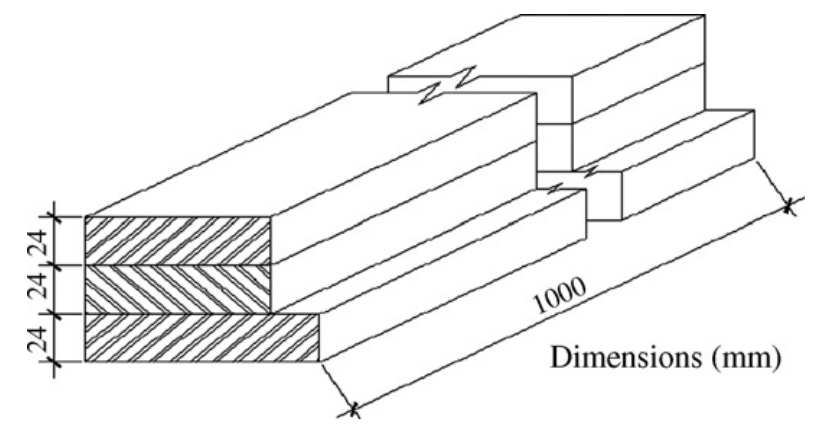

Figure 1. Schematics of laminated L shape window profile.

Specimens were divided into six treatment groups and for each group, a total of 20 test and 20 control samples were used. The samples were subjected to heat treatment at 150 and $180{ }^{\circ} \mathrm{C}\left( \pm 1^{\circ} \mathrm{C}\right)$ for 2, 6, and $10 \mathrm{~h}$ in a small heating unit under atmospheric pressure. The $\mathrm{MC}$ of the samples was 0 percent after heat treatment. After heat treatment, samples were conditioned to $12 \%$ moisture contents (MC) in a conditioning room at $20{ }^{\circ} \mathrm{C}\left( \pm 2^{\circ} \mathrm{C}\right)$ and with $65 \%( \pm 5)$ relative humidity $(\mathrm{RH})$ as specified in standard TS 642 and ISO 554. The equilibrium MC of the samples was approximately 12 percent after conditioning. 
Bending strength $\left(\sigma_{\mathrm{bB}}\right)$, modulus of elasticity $(\mathrm{MOE})$, and compression strength $\left(\sigma_{\mathrm{dB}}\right)$ tests were carried out on an Universal Testing System equipped with a load cell of 10 tonnes capacity. Tests of the compression strength parallel to grain (TS 2595, 1976), bending strength (TS 2474, 1976), and modulus of elasticity in bending (TS 2478, 1976) were carried out and the values were noted as treated and untreated (control) samples. Dimensions of the test samples are shown in Figure 2.

When the experiments were performed, the MCs (the MC deviation from 12 percent) of the specimens were measured according to standard TS 2471 (1976), and the strength values were corrected (transformed to $12 \%$ moisture content) using the following strength conversion equation:

$$
\delta_{12}=\delta_{\mathrm{m}} *\left[1+\alpha\left(\mathrm{M}_{2}-12\right)\right]
$$

where $\delta_{12}$ is the strength at $12 \% \mathrm{MC}(\mathrm{N} / \mathrm{mm} 2), \delta_{\mathrm{m}}$ is the strength at MC that deviated from 12 percent $(\mathrm{N} / \mathrm{mm} 2), \alpha$ is the constant value that shows the relationship between strength and MC $(\alpha=$ $0.06,0.04$, and 0.02 for $\sigma_{\mathrm{dB}}, \sigma_{\mathrm{bB}}$, and $\mathrm{MOE}$, respectively), and $\mathrm{M}_{2}$ is the $\mathrm{MC}$ during the experiment $(\%)$.
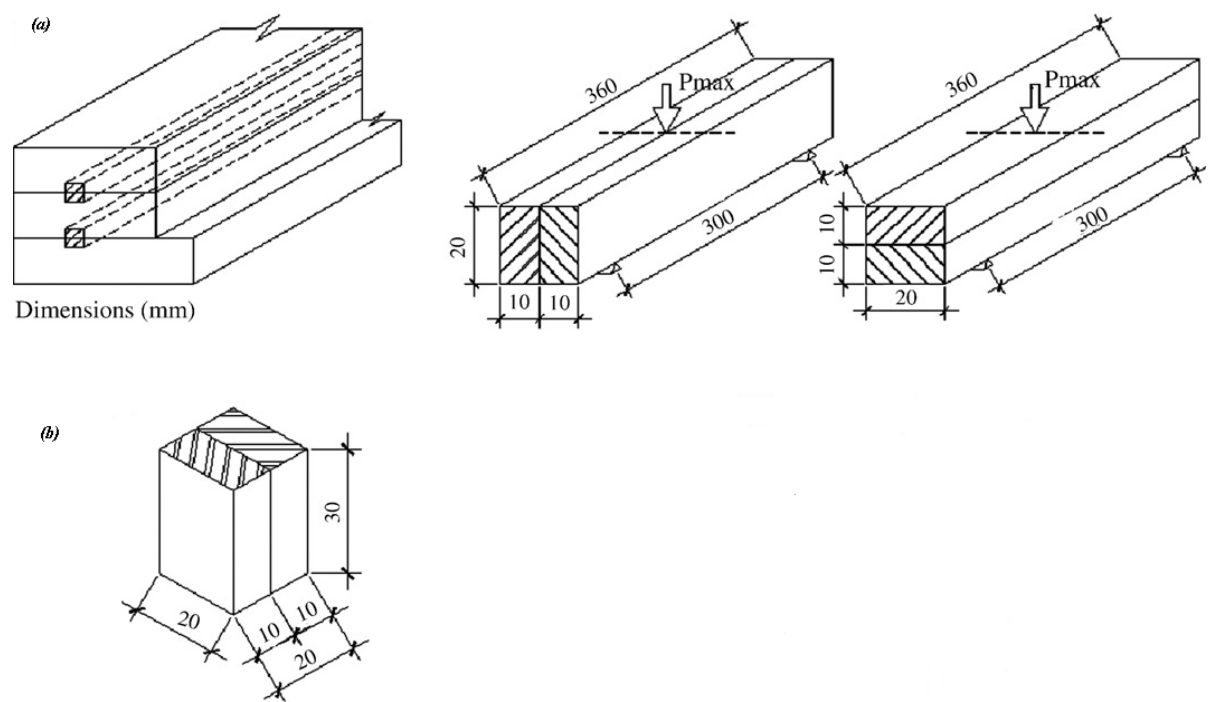

Figure 2. Dimensions of the test samples: (a) MOR and MOE, (b) compression strength.

The experimental results were statistically analyzed using analysis of variance (ANOVA), and significant differences between the control and the treated samples were determined using Duncan's Multiple Range Test (ASTM D 3110, 1998).

\section{Results and Discussion}

Table 1 shows the changes in the compression strength parallel to grain, bending strength, and modulus of elasticity in bending at varying treatment temperatures and durations. The results clearly indicate that heat treatment diminished the technological properties of Kosipo. ANOVA and Duncan's Multiple Range Tests show that all the differences were significant. However, compression strength was significantly influenced by temperature and time. Kosipo samples manufactured using UR 7221 adhesive had higher strength than those manufactured using PVAc.

It appears that adhesive type significantly influenced MOE values of the samples in both directions. 
The lower MOE value of $1008.99 \mathrm{~N} / \mathrm{mm}^{2}$ was determined for Kosipo profiles laminated in perpendicular direction to PVAc adhesive. However, average MOE value of Kosipo samples laminated with UR 7221 was found to be $11.27 \%$ greater than that of laminated samples using PVAc (1118 $\mathrm{N} / \mathrm{mm}^{2}$ vs. $1026.95 \mathrm{~N} / \mathrm{mm}^{2}$ ).

Table 2 shows the levels of decreases in strength values with increased thermal treatments. The greatest changes were realized at $180{ }^{\circ} \mathrm{C}$ and under $10 \mathrm{~h}$ treatment conditions. This level of treatments was also give the lowest compression strength value of $39.33 \mathrm{~N} / \mathrm{mm}^{2}$ and $43.20 \mathrm{~N} / \mathrm{mm}^{2}$ for UR 7221 and PVAc, respectively. These indicate $27.70 \%$ less strength for UR 7221 and $20.58 \%$ for PVActreated samples.

Similarly, the lowest bending-strength values were also obtained for the samples treated at $180{ }^{\circ} \mathrm{C}$ for $10 \mathrm{~h}$. The loss in bending strength for the heat-treated samples was found to be $31.84 \%, 46.36 \%$, $11.91 \%$, and $29.49 \%$ for profile laminated in parallel direction to UR7221 adhesive, profile laminated in perpendicular direction to UR7221, profile laminated in parallel direction to PVAc, and profile laminated in perpendicular direction to PVAc, respectively. The lowest modulus of elasticity in bending values was also obtained under similar treatment conditions. The decrease in modulus of elasticity in bending was found to be $14.45 \%$ for profile laminated in parallel direction to UR7221 adhesive, $22.80 \%$ for profile laminated in perpendicular direction to UR7221, 28.54 for profile laminated in parallel direction to PVAc, and $24.10 \%$ for profile laminated in perpendicular direction to PVAc, respectively.

It was also realized that lamination adversely influenced the overall strength properties of Kosipo specimens compared with those of solid wood. In general, the results of this study on the effect of heat treatment on Kosipo are compatible with the findings in the literature on the effect of heat treatment on different tree species. Vital et al. (1983) reported a study of compression parallel to grain in Eucalyptus saligna wood samples heated at $100-155{ }^{0} \mathrm{C}$ for $10-160 \mathrm{~h}$ and they found that the compression strength values generally deteriorated with increase in temperature or exposure time [19]. Dilik and Hiziroglu (2004) reported that Scotch pine with tangential-radial-tangential cross-section configuration using different layer thickness had the highest bending strength with an average of 99.22 $\mathrm{N} / \mathrm{mm}^{2}$ [2]. Dilik et al. (2007) found that the modulus of elasticity of Maritime pine (Pinus pinaster Ait.) samples laminated with PVAc and UR 7221 adhesives were 84.1, 78.8, 85.6, and 79.1 N/mm ${ }^{2}$ for directions perpendicular and parallel to lamination directions, respectively [20]. The results determined for Kosipo was generally consistent the reports found in the literature for various woods.

It was found that the compression strengths of laminated samples of Maritime pine were $8.3 \%$ greater than those of solid wood [20]. However, laminated samples of Kosipo had 10.4\% lower compression strength properties compared with those of solidwood. This is probably related to the chemical composition of wood samples and their behavior under heat treatment. Yildiz (2002) conducted a similar study with spruce (Picea orientalis L.) and beech (Fagus orientalis L.) woods at $200{ }^{\circ} \mathrm{C}$ for 6 -h conditions and reported a $36 \%$ decrease in compression strength [12]. Hence, loss in compression strength (10.4\%) for laminated Kosipo can be acceptable. Whereas a slight increase in compression strength was observed at $130{ }^{\circ} \mathrm{C}$ for 6 -h conditions. A number of studies were conducted for evaluating the effects of heat treatments on strength properties of woods. Consistently, bending strength and modulus of elasticity were reported to decrease up to $30-50 \%$ under drastic heattreatment conditions [21-24]. 
Table 1. Relationship between heat treatment based on treatment times and compression strength, bending strength, modulus of elasticity in bending. ${ }^{\text {a }}$

\begin{tabular}{|c|c|c|c|c|c|c|c|}
\hline & & Unit $^{b}$ & & Force & Compression Strength $^{\mathbf{c}}$ & Bending Strength $^{\mathrm{c}}$ & Modulus of Elasticity in Bending \\
\hline Heat Treatment & Times & Unit $^{-}$ & Glue & direction $^{\mathrm{d}}$ & $\mathrm{N} / \mathrm{mm}^{2}$ & $\mathrm{~N} / \mathrm{mm}^{2}$ & $\mathrm{~N} / \mathrm{mm}^{2}$ \\
\hline \multirow{8}{*}{ None } & & \multirow{8}{*}{$\begin{array}{l}\text { Avg. } \\
\pm \mathbf{s}\end{array}$} & \multirow{4}{*}{ UR 7221} & \multirow{2}{*}{ T.Y.P. } & \multirow{4}{*}{$\begin{array}{c}54.4 \mathrm{~A} \\
3.78\end{array}$} & $132.49 \mathrm{~A}$ & $1362.20 \mathrm{~A}$ \\
\hline & & & & & & 13.89 & 137.27 \\
\hline & & & & \multirow{2}{*}{ T.Y.D. } & & $142.36 \mathrm{~A}$ & $1387.04 \mathrm{~A}$ \\
\hline & & & & & & 18.67 & 159.14 \\
\hline & & & \multirow{4}{*}{ PVAc } & \multirow{2}{*}{ T.Y.P. } & \multirow{4}{*}{$\begin{array}{c}48.8 \mathrm{~A} \\
5.01\end{array}$} & $113.52 \mathrm{AB}$ & $1462.25 \mathrm{~A}$ \\
\hline & & & & & & 15.33 & 31.45 \\
\hline & & & & \multirow{2}{*}{ T.Y.D. } & & $117.88 \mathrm{~A}$ & $1329.49 \mathrm{~A}$ \\
\hline & & & & & & 11.25 & 135.10 \\
\hline \multirow{24}{*}{$150^{\circ} \mathrm{C}$} & \multirow{8}{*}{$2 \mathrm{hr}$. } & \multirow{8}{*}{$\begin{array}{l}\text { Avg. } \\
\pm \mathbf{s}\end{array}$} & \multirow{4}{*}{ UR 7221} & \multirow{2}{*}{ T.Y.P. } & \multirow{4}{*}{$\begin{array}{c}48.08 \mathrm{~A} \\
6.09\end{array}$} & $130.29 \mathrm{ACDEF}$ & $1312.59 \mathrm{ACDE}$ \\
\hline & & & & & & 6.21 & 168.05 \\
\hline & & & & \multirow{2}{*}{ T.Y.D. } & & 139.51 ABCDEF & 1254.14 AF \\
\hline & & & & & & 26.76 & 60.23 \\
\hline & & & \multirow{4}{*}{ PVAc } & \multirow{2}{*}{ T.Y.P. } & \multirow{4}{*}{$\begin{array}{c}47.14 \mathrm{ADEF} \\
3.74\end{array}$} & $113.13 \mathrm{AB}$ & 1399.54 AEF \\
\hline & & & & & & 12.55 & 183.63 \\
\hline & & & & \multirow{2}{*}{ T.Y.D. } & & 116.21 ADEF & $1305.37 \mathrm{ABC}$ \\
\hline & & & & & & 8.92 & 86.39 \\
\hline & & & \multirow{4}{*}{ UR 7221} & \multirow{2}{*}{ T.Y.P. } & \multirow{4}{*}{$\begin{array}{c}47.91 \mathrm{~A} \\
3.79\end{array}$} & 122.57 BEF & $1310.5 \mathrm{ACDE}$ \\
\hline & & & & & & 7.12 & 169.47 \\
\hline & & & & \multirow{2}{*}{ T.Y.D. } & & $123.98 \mathrm{BF}$ & $1235.07 \mathrm{BF}$ \\
\hline & $6 \mathrm{hr}$. & Avg. & & & & 21.65 & 63.97 \\
\hline & $\mathrm{o} \mathrm{nr}$. & $\pm \mathbf{s}$ & \multirow{4}{*}{ PVAc } & \multirow{2}{*}{ T.Y.P. } & & $109.53 \mathrm{AB}$ & 1316.20 BEF \\
\hline & & & & & $45.50 \mathrm{BF}$ & 13.29 & 121.94 \\
\hline & & & & \multirow{2}{*}{ T.Y.D. } & 4.66 & 109.25 BEF & $1303.92 \mathrm{ABC}$ \\
\hline & & & & & & 10.84 & 165.36 \\
\hline & & & & & & 119.7 CEF & 1268.01 BCDE \\
\hline & & & & I.Y.P. & $47.59 \mathrm{~A}$ & 7.93 & 99.64 \\
\hline & & & UR $/ 221$ & TY Y & 5.88 & $122.55 \mathrm{CF}$ & $1233.39 \mathrm{CF}$ \\
\hline & $10 \mathrm{hr}$ & Avg. & & 1.Y.D. & & 6.29 & 46.07 \\
\hline & $10 \mathrm{lll}$. & $\pm \mathbf{S}$ & & TYP & & $108.14 \mathrm{AB}$ & $1291.88 \mathrm{CF}$ \\
\hline & & & PVAc & 1.Y.P. & $45.02 \mathrm{C}$ & 16.60 & 25.45 \\
\hline & & & PVAC & & 3.50 & 108.59 CEF & $1283.16 \mathrm{ABC}$ \\
\hline & & & & T.Y.D. & & 3.72 & 83.92 \\
\hline
\end{tabular}




\begin{tabular}{|c|c|c|c|c|c|c|c|}
\hline \multirow{2}{*}{ Heat Treatment } & \multirow{2}{*}{ Times } & \multirow{2}{*}{ Unit $^{\mathbf{b}}$} & \multirow{2}{*}{ Glue } & \multirow{2}{*}{$\begin{array}{c}\text { Force } \\
\text { direction }^{\mathrm{d}}\end{array}$} & Compression Strength $^{\mathrm{c}}$ & Bending Strength $^{\mathrm{c}}$ & Modulus of Elasticity in Bending ${ }^{c}$ \\
\hline & & & & & $\mathrm{N} / \mathrm{mm}^{2}$ & $\mathrm{~N} / \mathrm{mm}^{2}$ & $\mathrm{~N} / \mathrm{mm}^{2}$ \\
\hline \multirow{24}{*}{$180^{\circ} \mathrm{C}$} & \multirow{8}{*}{$2 \mathrm{hr}$. } & \multirow{8}{*}{$\begin{array}{l}\text { Avg. } \\
\pm \mathbf{s}\end{array}$} & \multirow{4}{*}{ UR 7221} & \multirow{2}{*}{ T.Y.P. } & \multirow{4}{*}{$\begin{array}{c}45.76 \mathrm{~A} \\
2.58\end{array}$} & 116.20 DEF & $1183.33 \mathrm{C}$ \\
\hline & & & & & & 23.84 & 97.39 \\
\hline & & & & \multirow{2}{*}{ T.Y.D. } & & $119.0 \mathrm{DF}$ & $1159.4 \mathrm{D}$ \\
\hline & & & & & & 7.63 & 101.10 \\
\hline & & & \multirow{4}{*}{ PVAc } & \multirow{2}{*}{ T.Y.P. } & \multirow{4}{*}{$\begin{array}{c}43.70 \mathrm{D} \\
1.85\end{array}$} & $105.66 \mathrm{AB}$ & $1281.69 \mathrm{DF}$ \\
\hline & & & & & & 5.95 & 105.18 \\
\hline & & & & \multirow{2}{*}{ T.Y.D. } & & $103.75 \mathrm{DF}$ & $1250.68 \mathrm{ABC}$ \\
\hline & & & & & & 16.24 & 153.60 \\
\hline & \multirow{8}{*}{$6 \mathrm{hr}$. } & \multirow{8}{*}{$\begin{array}{l}\text { Avg. } \\
\pm \mathbf{s}\end{array}$} & \multirow{4}{*}{ UR 7221} & \multirow{2}{*}{ T.Y.P. } & \multirow{4}{*}{$\begin{array}{c}44.47 \mathrm{~B} \\
3.06\end{array}$} & $99.60 \mathrm{EF}$ & $1167.93 \mathrm{D}$ \\
\hline & & & & & & 7.84 & 140.82 \\
\hline & & & & \multirow{2}{*}{ T.Y.D. } & & $114.90 \mathrm{EF}$ & $1152.33 \mathrm{E}$ \\
\hline & & & & & & 14.49 & 144.66 \\
\hline & & & \multirow{4}{*}{ PVAc } & \multirow{2}{*}{ T.Y.P. } & \multirow{4}{*}{$\begin{array}{c}43.47 \mathrm{E} \\
2.52\end{array}$} & $105.35 \mathrm{AB}$ & $1155.35 \mathrm{E}$ \\
\hline & & & & & & 14.46 & 229.92 \\
\hline & & & & \multirow{2}{*}{ T.Y.D. } & & $98.2 \mathrm{EF}$ & $1034.67 \mathrm{~B}$ \\
\hline & & & & & & 14.73 & 96.21 \\
\hline & \multirow{8}{*}{$10 \mathrm{hr}}$. & \multirow{8}{*}{$\begin{array}{l}\text { Avg. } \\
\pm \mathbf{s}\end{array}$} & \multirow{4}{*}{ UR 7221} & \multirow{2}{*}{ T.Y.P. } & \multirow{4}{*}{$\begin{array}{c}39.33 \mathrm{C} \\
5.04\end{array}$} & $90.30 \mathrm{~F}$ & $1165.25 \mathrm{E}$ \\
\hline & & & & & & 13.59 & 60.30 \\
\hline & & & & \multirow{2}{*}{ T.Y.D. } & & $76.35 \mathrm{~F}$ & $1070.76 \mathrm{~F}$ \\
\hline & & & & & & 7.52 & 166.11 \\
\hline & & & & & & $100.0 \mathrm{~B}$ & $1044.92 \mathrm{~F}$ \\
\hline & & & PVAc & T.Y.P. & $43.20 \mathrm{~F}$ & 12.62 & 116.15 \\
\hline & & & PVAc & & 2.49 & $83.11 \mathrm{~F}$ & $1008.99 \mathrm{C}$ \\
\hline & & & & T.Y.D. & & 19.56 & 121.49 \\
\hline
\end{tabular}

${ }^{\mathrm{a}}$ Number of samples used in each test is 20 .

${ }^{\mathrm{b}}$ Avg. $=$ average $; \mathrm{s}$ = standard deviation

${ }^{\mathrm{c}}$ Homogenous groups: letters in each column indicate groups that are statistically different according to Duncan's multiple range test at $\mathrm{P}<0.05$.

${ }^{\mathrm{d}}$ T.Y.D., perpendicular to laminating direction; T.Y.P., parallel to laminating direction.

Comparisons were between each control and its test. 
Table 2. Decreasing based on temperature and times in heat treatment.

\begin{tabular}{|c|c|c|c|c|c|c|}
\hline \multirow{2}{*}{$\begin{array}{c}\text { Heat } \\
\text { Treatment }\end{array}$} & \multirow[t]{2}{*}{ Times } & \multirow[t]{2}{*}{ Glue } & \multirow{2}{*}{$\begin{array}{c}\text { Annual } \\
\text { ring } \\
\text { position }\end{array}$} & $\begin{array}{c}\text { Compression } \\
\text { Strength }\end{array}$ & Bending Strength & $\begin{array}{c}\text { Modulus of Elasticity in } \\
\text { Bending }\end{array}$ \\
\hline & & & & $\%$ & $\%$ & $\%$ \\
\hline \multirow{12}{*}{$150^{\circ} \mathrm{C}$} & \multirow{4}{*}{$2 \mathrm{hr}$. } & & T.Y.P. & \multirow{2}{*}{10.29} & 1.66 & 3.64 \\
\hline & & UR 7221 & T.Y.D. & & 2.00 & 9.58 \\
\hline & & \multirow{3}{*}{ PVAc } & T.Y.P. & \multirow{2}{*}{13.34} & 0.34 & 4.28 \\
\hline & & & T.Y.D. & & 1.42 & 1.81 \\
\hline & \multirow{5}{*}{$6 \mathrm{hr}$. } & & T.Y.P. & & 7.48 & 3.79 \\
\hline & & UR 7221 & T.Y.D. & 11.93 & 12.91 & 10.95 \\
\hline & & \multirow{3}{*}{ PVAc } & T.Y.P. & \multirow{3}{*}{16.36} & 3.51 & 9.98 \\
\hline & & & T.Y.D. & & 7.32 & 1.92 \\
\hline & & & T.Y.P. & & 9.65 & 6.90 \\
\hline & \multirow{3}{*}{$10 \mathrm{hr}$} & UR 7221 & T.Y.D. & 12.51 & 13.91 & 11.07 \\
\hline & & \multirow{2}{*}{ PVAc } & T.Y.P. & \multirow{2}{*}{17.24} & 4.74 & 11.65 \\
\hline & & & T.Y.D. & & 7.88 & 3.48 \\
\hline \multirow{12}{*}{$180^{\circ} \mathrm{C}$} & \multirow{4}{*}{$2 \mathrm{hr}}$. & \multirow{4}{*}{$\begin{array}{c}\text { UR } 7221 \\
\text { PVAc }\end{array}$} & T.Y.P.. & \multirow{3}{*}{15.88} & 12.29 & 13.13 \\
\hline & & & T.Y.D. & & 16.41 & 16.41 \\
\hline & & & T.Y.P. & & 6.92 & 12.34 \\
\hline & & & T.Y.D. & 19.66 & 11.98 & 5.92 \\
\hline & \multirow{4}{*}{$6 \mathrm{hr}}$. & \multirow{2}{*}{ UR 7221} & T.Y.P. & \multirow{3}{*}{18.25} & 24.82 & 14.26 \\
\hline & & & T.Y.D. & & 19.28 & 16.92 \\
\hline & & \multirow{2}{*}{ PVAc } & T.Y.P. & & 7.19 & 20.98 \\
\hline & & & T.Y.D. & \multirow[t]{2}{*}{20.09} & 16.69 & 22.17 \\
\hline & \multirow{4}{*}{$10 \mathrm{hr}$} & \multirow{2}{*}{ UR 7221} & T.Y.P. & & 31.84 & 14.45 \\
\hline & & & T.Y.D. & \multirow[t]{2}{*}{27.70} & 46.36 & 22.80 \\
\hline & & PVAc & T.Y.P. & & 11.91 & 28.54 \\
\hline & & PVAC & T.Y.D. & 20.58 & 29.49 & 24.10 \\
\hline
\end{tabular}

A number of studies have been conducted on the reasonably explanation for heat treatment of woods. However, most studies have shown that the strength properties of woods are reduced upon heating. Consistently, the decrease of the strength properties of heat treated woods because of changes in the basic structure of wood constituents. The decreases in the strength properties depended on the treatment conditions and on the chemical constituents of woods, which is attributed to the depolymerization reactions of wood polymers during the thermal degradation $[25,26]$. Particularly, lignin and hemicelluloses, which are less resistant to heat than cellulose, are the primary factors for loss in strength in high-temperature treatments [27]. However, it is probable that heat can be plasticizer to cell wall and effects increasing kinetic energy of molecules, hence, strength of laminated wood samples can be decreased.

\section{Conclusions}

On the basis of the initial results, it appears that the production of laminated window profiles from Kosipo would be considered as an alternative method to use raw material more efficiently without having any adverse effect on their properties. The findings of the experiments are comparable to those studies previously carried out in such area. Both types of adhesives resulted in significant differences in their strength characteristics at 95\% confidence level. Adhesive UR 7221 improved the overall properties of the samples in contrast to PVAc. Using laminated profiles in window manufacturing would also result in sustainable management of forest resources. In further studies, profiles 
manufactured using various press parameters such as different pressure levels and press time could be desirable to obtain better information about the properties of the profiles.

\section{Acknowledgements}

Assistance of technical staff members of Akcam Joinery Inc., Istanbul for sample preparation is greatly appreciated.

\section{References and Notes}

1. Dilik, T. Production of window profiles from laminated lumber and determination of manufacturing factors. Ph.D. Thesis, Istanbul University, Istanbul, Turkey 1997.

2. Dilik T.; Hiziroglu, S.S. Effect of density and some of the production parameters on bending strength of laminated window profiles. Journal of Building and Environment 2004, 39, 1199-1205.

3. Kurtoglu, A. Moisture distribution in laminated layered loud bearing thick wood materials. Review of the Faculty of Forestry, Series-A 1978, 28(1).

4. Kurtoglu, A. The occurrence of stress in laminated layered wood materials due to moisture change. Review of the Faculty of Forestry, Series A 1979, 29(2)

5. Moody, R.C. Compressive strength of one-and two-ply laminated timbers. Forest Product. J. 1981, 31(5).

6. Laufenberg, T. Exposure effect upon performance of laminated veneer lumber and glulam materials. Forest Prod. J. 1982, 32(5), 42-48.

7. Schimid J. Laminated timber window frames in cross-section. Holzzentralblatt 1984, 110(8), 104-105.

8. Lejeune P.; Leclercq, A. Technological study on the upgrading of small sized indigenous oaks by lamination. Bull. des Recherches Agronomigues de Gembloux 1990, 25(3), 313-328.

9. Turkulin, H. Durability of laminated wooden window profiles: moisture content distribution and dimensional stability. Holz Roh-Werkst. 1992, 50(9), 347-352.

10. Turkulin, H. Durability of laminated wooden window profiles: investigations on delamination and glue-bond strength. Holz Roh-Werkst. 1993, 51(1), 67-71.

11. Mazela, B.; Zakrzewski, R.; Grzes' Kowiak, W.; Cofta, G.; Bartkowiak, M. Resistance of thermally modified wood to basidiomycetes. Wood Technology 2004, 7(1), 253-62.

12. Yildiz, S. Physical, mechanical, technological and chemical properties of beech and spruce wood treated by heating. Ph.D. Thesis, Black Sea Technical University, Trabzon, Turkey, 2002.

13. Syrjanen, T.; Oy, K. Production and classification of heat treated wood in Finland. In Review on heat treatments of wood; Proceedings of the special seminar held in Antibes, France, 2001.

14. Rapp, A.O. In Review on heat treatments of wood; Proceedings of the special seminar held in Antibes, France, 2001.

15. Jämsä S.; Viitaniemi, P. Heat treatment of wood better durability without chemicals. In: Rapp AO,editor. In: Review on heat treatments of wood. Cost Action E22, 2001. 
16. Militz, H. Thermal treatment of wood: European processes and their background. In Proceedings of the 33rd Annual Meeting, Cardiff-Wales, 12-17 May, 2002, IRG/WP 02-40241; Vol. 4, p. $1-17$.

17. Mitchell, P.H. Irreversible property changes of small loblolly pine specimens heated in air, nitrogen, or oxygen. Wood and Fiber Science 1988, 20(3), 320-355.

18. Anonymous. Laminating of window profiles for wood windows instructions. In I.F.T. Richtlinie; IFT Institute für Fenstertechnik e.V.: Rosenheim, Germany, 1986.

19. ASTM D 3110. Standard Specification for Adhesives Used in Nonstructural Glued Lumber Products, 1988.

20. Vital, B.R.; Lucia R. M.; Euclides, R. F. Effect of Heating on Some Poperties of Eucalyptus saligna Wood. Revista-Arvore 1983, 7(2), 136-146.

21. Dilik, T.; Dündar, T.; Kurtoğlu, A.; Hiziroglu, S.S. Effect of adhesive types on some of the properties of laminated window profiles. Journal of Materials Processing Technology 2007, 18(9), 320-324.

22. Giebeler, E. Dimensional stabilization of wood by moisture-heatpressure. Holz Roh-Werkst. 1983, 41, 87-94.

23. Kubojima, Y.; Okano, T.; Ohta, M. Bending strength and toughness of heat-treated wood. Journal of Wood Science 2000, 46, 8-15.

24. Rusche, H. Strength properties of dried wood after heat treatment. Holz Roh Werks. 1973, 31, 273-281.

25. Bekhta, P.; Niemz, P. Effect of high-temperature on the change in color, dimensional stability and mechanical properties of spruce wood. Holzforschung 2003, 57, 539-546.

26. Kotilainen, R. Chemical changes in wood during heating at $150-260^{\circ} \mathrm{C}$. Ph.D. Thesis, Jyva skyla University, Finland, 2000.

27. Wikberg, H.; Maunu, S.L. Characterization of thermally modified hard- and softwoods by $13 \mathrm{C}$ CPMAS NMR. Carbohydrate Polymer 2004, 58, 461-466.

28. Hillis, W.E. High-temperature and chemical effects on wood stability. Wood Science and Technology 1984, 18, 281-293.

29. DIN-EN 204: Classification of thermoplastic wood adhesives for nonstructural applications, 2004.

30. PrEN 386: Glued laminated timber production requirements, 1991.

31. TS EN 390: Glued laminated timber, dimensions and allowable deviations, Ankara-Turkey, 1999.

32. TS 2860: Wooden window requirements, Ankara-Turkey, 1978.

33. TS-5430: Turkish Standardization Institute, Ankara, Turkey, 1988.

34. TS 642 ISO 554: Standard atmospheres for conditioning and/or testing; specifications, Ankara, 1997.

35. TS 2595: Wood-determination of ultimate stress in compression parallel to grain, Ankara, 1976.

36. TS 2474: Wood-determination of ultimate strength in static bending, Ankara, 1976.

37. TS 2478: Wood-determination of modulus of elasticity in static bending, Ankara, 1976.

38. TS 2471: Wood-determination of moisture content for physical and mechanical tests, Ankara, 1976.

(C) 2008 by MDPI (http://www.mdpi.org). Reproduction is permitted for noncommercial purposes. 